\title{
Improvement on Curriculum System Settings in Project Cost Major of Higher Education Based on Grounded Theory
}

\author{
Xia Liming, Wang Sisi \\ School of Management, Tianjin University of technology, Tianjin 300384, China
}

352117645@qq.com

Keywords: Curriculum System of Higher Education; Project cost; Grounded theory

\begin{abstract}
From the reality that talent training at our current cost engineering curriculum system does not match engineering industry needs, by using grounded theory method, we explore four factors associated with cost engineering curriculum system setting-platform courses, career stage, course system, colleges-enterprises unities, and got three kinds of logical relationships between them interrelated: Technology-Economy-Law-Management Course has different roles at different career stages; we can improve curriculum system settings to make platform courses match with career stages; two-pronged approach-improving curriculum and colleges- enterprises unities-is an effective way to achieve these goals. Finally, the paper proposed suggestions for improvement curriculum corresponding with our findings. We think that colleges should attach importance to the technology platform courses, practice-oriented teaching and colleges-enterprises unities in order to meet industry demand for cost engineering personnel.
\end{abstract}

\section{Introduction}

Project cost is a borderline of interdisciplinary subject, with engineering technology, economy, management, law and some other knowledge categories. It aims at cultivating senior management talents who can be engaged in the whole process of cost management in engineering construction field at home and abroad ${ }^{[1]}$.In recent years, the development of Chinese construction industry achieved by leaps and bounds, growing construction talents crisis is becoming severe. The scarcity of management talent in construction is one of the important reasons in restricting the further development of construction industry in our country ${ }^{[2]}$. Engineering construction field in our country urgently need to meet the senior management talents who can adapt to the needs of modernization ${ }^{[3]}$.Curriculum system as knowledge carrier ${ }^{[4]}$ of talent training, to determine whether the project cost majors have the ability to work for companies after graduation, however, students' mastery of professional knowledge is not enough to achieve all-round and comprehensive effect in practice, so that their career adaptation ability is poor and adjustment period is long ${ }^{[5]}$.In view of the problem that existing curriculum system on project cost major cannot satisfy the requirements of enterprise, from the micro level of curriculum, this article, using the method of grounded theory, will research about how to improve existing engineering cost course system in order to match the reality demand of the enterprise.

\section{The Statues of Curriculum System Settings in Project Cost Major of higher education at home and abroad}

The Statues of Curriculum System Settings in Project Cost Major of foreign higher education. Project cost discipline education system is represented by the quantity surveying (QS) system of the United Kingdom and the project cost (CE) system of the United States, training of professionals in the construction cost on the curriculum system settings, are the implementation of the industry to learn cost of certification system of higher education curriculum system, combined with a sound professional associations involved in the system, forming a qualification system and the integration of the project cost of higher education training system ${ }^{[6]}$. On abroad, the industry learned ensure that the curriculum system and teaching content can satisfy the industry's ability to learn and the market for project cost personnel requirements, through the system of certification 
system of the project cost on college course (Accreditation System). The curriculum settings is based on engineering technology classes, while focusing on the integration of technology, economics, management and law subjects ${ }^{[7]}$. American higher education Curriculum Settings basically gives priority to engineering disciplines, supplemented by content management discipline. In addition, foreign curriculum system in project cost attaches great importance to the students' practical ability, practical teaching occupies a large proportion in the curriculum system. Measuring Workshop (Surveying Studio) practice teaching is the most characteristic in practical teaching, using the workshop approach, combined with case teaching method, integrating the technical, economic, regulatory and legal knowledge. In addition, there are a large number of internships to ensure that students can gain the specialized skills to access in the relevant field of work.

The Statues of Curriculum System Settings in Project Cost in our country. Analysis on the Statues of Curriculum System Settings in Project Cost in our country. In china, the project cost of undergraduate education mostly orientated to the form of specialized engineering management, only a few colleges and universities set up a special undergraduate major in engineering cost. Since China Construction Specialty is still in the development stage, setting up in University Curriculum System project cost contains many shortcomings. At present the institutions about Curriculum System Construction Major mostly belonging to different departments, generally subordinated to three faculties, namely, civil engineering, finance, economics and management hospital, leading the difference in professional knowledge to universities. Due to the lack of guidance of industry associations, the purpose of our curriculum system in construction cost of Higher Education are not clear, curriculum system is just more than a simple sum of the technical, economic, regulatory and legal class curriculum. In practice teaching, lacking of overall planning and organization. There are two main forms: first, the basic course teaching theory lags behind practice teaching required in relevant content; the second is the lack of appropriate training on Theory Course. In our country, the practical process in Course System Engineering Practice is presented in two ways: curriculum design and professional practice, but the effect is not obvious, Graduates still can not achieve the requirements which industry association of professional ordered.

Research on the improvement of Curriculum System in Project Cost in our country. Based on the existing problems in Project Cos tof Higher Education Curriculum System, domestic scholars proposed improving theories and methods. Chen Jianguo, Xiuming, and others carried out an integrate analysis on project management courses which is based on core knowledge and ability, after the analysis on professional project management situation on the syllabus, using the core main method to sort out and optimize project management courses syllabus ${ }^{[8]}$. Easy to find by the above literature review, previous studies scholars are used to improve the curriculum system experience and theoretical analysis, lacking of scientific research methods. Therefore, this article will be based on previous studies, first, putting the grounded theory into the improvement of course system in order to get more scientific, more profound way to improve curriculum.

\section{Application of Grounded Theory Research Methods}

Curriculum system is the sum of the content and process of teaching; curriculum order category determines what knowledge of the structure students will gain through learning. Curriculum system settings directly determine whether students have complete knowledge structure and capability ${ }^{[9]}$. Improvement about curriculum system in Project Cost is to achieve the purpose of improving students' comprehensive ability from the new teaching methods and content adjustment. Through literature study, in terms of the curriculum system in project cost of higher education can not satisfy the actual needs of industry, this paper focuses on: (1) the effect about four courses category of project cost namely, technology, economics, management and law at different stages ; (2) whether the curriculum by providing improved platform to achieve matches between the platform class categories and career development stage; (3) whether improvements of curriculum system can ensure that students can qualify the required knowledge structure which is needed in cost consulting graduation work, and how to improve the curriculum system. 
Data collection and collation. This study adopts the way of focus group interviews. Respondents are actual staff in certain engineering cost consulting industry in Tianjin, including 15 management staff, 30 technical staff, each interview lasted about 1.5 hours. In this study, 45 samples data were collected, analyzed the data records which is consisted of interview recording and interview notes.

Open decoding. Open coding is a process which break sthe original interview data, takes out concept, combine it in new ways again. In the process of decoding, first, analyzing the interview data coding word by word, using the interviewee words as tags as far as possible in order to dig the initial concept, so that we can minimize the researcher's personal biases, mindset, or influence, then making the large number of initial concept into further refinement, putting the relevant concepts together and achieving category. Through data sorting of depth interview, specific open decoding analysis results are shown in table 1:

Table 1: Open coding analysis

\begin{tabular}{|c|c|c|}
\hline $\begin{array}{c}\text { Serial } \\
\text { number }\end{array}$ & category & concept \\
\hline 1 & $\begin{array}{l}\text { Professional } \\
\text { skills }\end{array}$ & $\begin{array}{l}\text { The basic professional skills: knowledge chart, skilled application norm estimate, budget and bid } \\
\text { quotation, etc. }\end{array}$ \\
\hline 2 & $\begin{array}{l}\text { Legal } \\
\text { knowledge }\end{array}$ & $\begin{array}{l}\text { For cost consultation unit, at least, the graduates should be familiar with contract law, the bidding } \\
\text { method and so on several common law. }\end{array}$ \\
\hline 3 & $\begin{array}{l}\text { Economic } \\
\text { knowledge }\end{array}$ & $\begin{array}{l}\text { To not only have some knowledge of engineering economics, but also need to understand the } \\
\text { knowledge on finance and accounting. }\end{array}$ \\
\hline 4 & $\begin{array}{l}\text { Ability to } \\
\text { manage }\end{array}$ & $\begin{array}{l}\text { When entering management, students are required to have a fairly ability to plan as a whole, } \\
\text { coordination, organization, etc. }\end{array}$ \\
\hline 5 & Business level & $\begin{array}{l}\text { For college students graduated from } 1 \sim 5 \text { years, in the stage of learning and progress, need to work } \\
\text { under the guidance of the project leader to finish better. }\end{array}$ \\
\hline 6 & $\begin{array}{l}\text { The } \\
\text { management } \\
\text { level }\end{array}$ & $\begin{array}{l}\text { When move into management, you need to use your own knowledge and ability to lead the whole } \\
\text { project team to do a good job and is more of a management coordination. }\end{array}$ \\
\hline 7 & $\begin{array}{l}\text { Development } \\
\text { level }\end{array}$ & $\begin{array}{l}\text { As a manager, chairman of the kinds of directors of the enterprise senior leaders, considering more } \\
\text { is enterprise management problems, such as the enterprise development strategy, organizational } \\
\text { structure, how to arouse the enthusiasm of staff and so on. }\end{array}$ \\
\hline 8 & $\begin{array}{l}\text { The theoretical } \\
\text { knowledge }\end{array}$ & $\begin{array}{l}\text { In practical work, theoretical knowledge is not much, uses mostly knowledge chart, project } \\
\text { valuation, construction technology and some partial knowledge of the field. }\end{array}$ \\
\hline 9 & Practice & $\begin{array}{l}\text { Practice courses use much more in practice, practical courses like CAD, can appropriately increase } \\
\text { the teaching content of courses. }\end{array}$ \\
\hline 10 & Internship & $\begin{array}{l}\text { For students, the biggest help which come from internships is it can make the students more close } \\
\text { to and learn about the society, resulting in the pressure and motivation of learning, and adapt to the } \\
\text { working condition in advance. }\end{array}$ \\
\hline 11 & $\begin{array}{l}\text { Enterprise } \\
\text { needs }\end{array}$ & $\begin{array}{l}\text { Enterprises need more solid basic knowledge and the students with technical ability, such students } \\
\text { can quickly enter the work state, and then also look at some factors such as the candidate's attitude, } \\
\text { personality and so on. }\end{array}$ \\
\hline \multicolumn{3}{|c|}{$\begin{array}{l}\text { Axial coding. The task of axial coding is to find and establish potential logical relationship } \\
\text { tween the different category in open coding through cluster analysis, forming into a more general } \\
\text { tegory. For this, interview in open coding which can present this link will be analyzed one by one, } \\
\text { ing to parse the latent context or causal relationship. Regarding the form which come from open } \\
\text { coding, "technology", "law", "economy" and "management" as four sub-categories belong to the } \\
\text { latform courses";putting three sub-categories, namely, "business layer", "management layer" and } \\
\text { evelopment layer" into affiliation of the "professional stage ";putting "theory of knowledge" and } \\
\text { ractical program" into affiliation of the "curriculum category";putting" internship" and "enterprise } \\
\text { eds" into affiliation of the "school-enterprise cooperation "category. After analyzing, four generic } \\
\text { pes are extracted, the main category and relevant concepts are shown in table } 2 \text {. }\end{array}$} \\
\hline
\end{tabular}


Table 2: the main category and connotation formed by axial coding

\begin{tabular}{|c|c|c|}
\hline & Main category & connotation \\
\hline 1 & Platform course & $\begin{array}{l}\text { Technology, law, economics and management build platform course system together, building the } \\
\text { basis of professional course system project cost. For the project cost professional graduates, the } \\
\text { knowledge of these four courses is mainly used in the later career. }\end{array}$ \\
\hline 2 & $\begin{array}{l}\text { Professional } \\
\text { stage }\end{array}$ & $\begin{array}{l}\text { At this point in a business hierarchy, about } 1 \sim 5 \text { years after graduation and even the more, } \\
\text { engaging in basic work, (such as quantity, pricing, etc.); As project manager or department head } \\
\text { enter into the middle management, the later stage of development is called development layer. }\end{array}$ \\
\hline 3 & $\begin{array}{l}\text { Curriculum } \\
\text { system }\end{array}$ & $\begin{array}{l}\text { Theoretical knowledge refers to the course and knowledge mainly are given by professor in class, } \\
\text { and practical program is outside of the classroom activities that gives priority to exercising of } \\
\text { students' practice ability, both constitute curriculum system of higher education. }\end{array}$ \\
\hline 4 & $\begin{array}{c}\text { School-enterprise } \\
\text { cooperation }\end{array}$ & $\begin{array}{l}\text { Internship is a main form for students to use their learned knowledge in school into in practical } \\
\text { work. The enterprise needs is put forward to satisfy its own development demand for talent } \\
\text { structure, two-way cooperation of colleges and enterprises is an effective way to realize the goal } \\
\text { of both school and enterprise. }\end{array}$ \\
\hline
\end{tabular}

Selective decoding. Selective coding in this article is to systematically explore the correlation of the category and the sub-category. From the main categories to dig out the category of "core", analyzing coupling connection between the core categories and main category and other categories, and depicting the behavior phenomenon and context conditions in the form of "story line". Through researching in the potential thread of main categories and concepts, finding that main category existed three kinds of logic relation before, which is shown in table 3:

Table 3:typical relational structures of main categories

\begin{tabular}{|c|c|c|}
\hline $\begin{array}{c}\text { Serial } \\
\text { number }\end{array}$ & typical relational structures & Relational structure connotation \\
\hline 1 & Platform course $\rightarrow$ Professional stage & $\begin{array}{l}\text { By summing up, demand is different for platform course knowledge at } \\
\text { different career stage, four platform courses that technology - } \\
\text { economy - law -management play a different role in different stages } \\
\text { of career. }\end{array}$ \\
\hline 2 & Platform course $\rightarrow$ Prơfessional stage & $\begin{array}{l}\text { The matching demands of platform course structure and professional } \\
\text { stage can beachieved by improving curriculum system settings. }\end{array}$ \\
\hline 3 & Platformcourse $\rightarrow$ Professional stage & $\begin{array}{l}\text { Improving the curriculum system setting and achieving } \\
\text { school-enterprise cooperation together, can reach the dual goal that } \\
\text { school fosters talents and the demand of enterprise. }\end{array}$ \\
\hline
\end{tabular}

By the method of grounded theory, this article first from the original information of the interview extract scattered concepts, the next, will be scattered, clustering scattered concepts into four main categories, finally obtaining main category existed three kinds of logic relation before by analyzing.

\section{Conclusions and Outlook}

Through literature analysis, focus group interviews and research based on grounded theory analysis, three conclusions can gain from this article: (1) Four Division Platform: Technology Economy - Law - Management plays different roles at different career stages, for workers at the business level, the role of the largest is technology courses; and for management level, the needs of the economy and legal platform courses are increased; development level need much greater requirement for management, concept, and summary. Business has the maximum of demand in technology platforms curriculum. (2) The study found that curriculum system settings in higher education should be based on technology courses, and combine with other categories of economic, legal and management courses. Improving the proportion of engineering and technology courses in 
the engineering curriculum system; at the same time, carrying out the workshop (Studio) and other practical teaching, making technical, economic, legal and management platform courses into combination. (3) Studies have shown that the curriculum system can be improved to ensure that students graduate with the needed knowledge structure when they engaged in cost consulting work. In this paper, the Curriculum System in project cost of Higher Education has a certain reference value. But the problem may be not completely considered about the basic courses and orientation courses of the project cost major. In subsequent studies, we can stand beyond this research experience, expanding the scope of research and making further improve on curriculum system of project cost major.

\section{Reference}

[1] Wang Tong, PANG Yong division Research and Practice Experimental Teaching System project cost. China University Teaching, 2011, (1): 77-79.

[2] Dong Yu. Construction need to break through the bottleneck of talent.Http://cpc.people.com.cn/GB/64107/64109/8368490.html\#. 2008-11-19 / 2015-8 -8

[3] Chen Jianguo, Li Xiuming, Liu silver, had Daelim Engineering Management Professional Core Syllabus and optimization . Higher Engineering Education Research, 2013,05: 135-139.

[4] Li Qingfeng strengthen guidance and promote the Curriculum System of Evaluation. Chinese higher education, 2014,09: 35-37.

[5] REN Hong, Yan Yonggang engineering management professional platform Curriculum Model and Teaching System Integration Innovation. Higher Engineering Education Research, 2009,02: 80-83.

[6] Sun Chunling, Yin Yi Lin International Engineering Cost professional integration of higher education and vocational qualification training model study, the Second China Forum on Management Science and Engineering, 2004,11. Shanghai.

[7] Fellows R. Cost of Practice. Liaomei Wei, Beijing: China Building Industry Press, 2001: 1-4

Xue Xiangheng comparative study

[8] abroad Construction Specialty Course System.Career Horizon, 2007,24: 64-65. 